Original Article

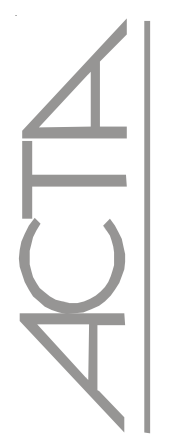

\title{
Perineal outcomes on the left lateral versus vertical semi- sitting birth positions: a randomized study*
}

\author{
Resultado perineal nas posições de parto lateral esquerda versus vertical semi-sentada: estudo \\ randomizado \\ Resultado perineal en las posiciones de parto lateral izquierdo versus vertical semi-sentada: estudio \\ randomizado
}

Janine Schirmer ${ }^{1}$, Suzete Maria Fustinoni ${ }^{2}$, Anatália Lopes de Oliveira Basile ${ }^{3}$

\begin{abstract}
Objective: To evaluate the perineal outcomes in unconventional birth positions. Methods: A randomized clinical study. Conducted in a birth centre in the city of Itapecerica da Serra, Brazil. A sample of 158 nulliparas, divided randomly into the left lateral position (81 experimental) and upright half-sitting (77 - control). Results: Experimental group showed less vulvar edema, 13.6\% vs. 29.9\%, OR 2.71 (95\% IC $1.22-6.02$ ), episiotomy, $16.0 \%$ vs. 35.1 OR 2,46 (95\% IC $1,27-4.74$ ), and more labial lacerations 37,0\% vs. 19,5\% OR 2,43 (95\% IC $1,18-5,51)$. The women who adopted the upright half-sitting position had a lower risk of first-degree laceration $(37,7 \%$ versus $56,8 \%)$. However, they had a higher risk of second-degree laceration and frequency of episiotomy OR 2,11 (95\% IC 1,02 - 4,35). The presence of vulvar edema increased the risk of spontaneous trauma and episiotomy OR 3,99 (95\% IC 1,80 - 8,85). Conclusions: Our data confirmed the hypothesis that the left lateral position offers less risk of serious perineal traumas.

Keywords: Obstetrical nursing; Midwifery/methods; Natural childbirth/methods; Posture; Perineum/injuries
\end{abstract}

\section{RESUMO}

Objetivo: Avaliar se existe associação entre o resultado perineal em posições de parto não convencionais. Métodos: Estudo clínico randomizado realizado no Centro de Parto Normal da cidade de Itapecerica da Serra, São Paulo, Brasil. A amostra foi constituida por 158 nulíparas divididas aleatoriamente na posição de parto lateral esquerda (81 no grupo experimental) e vertical semi-sentada (77 no grupo controle). Resultados: As mulheres do grupo experimental apresentaram menor edema vulvar - 13,6\% vs 29,9\%, OR 2.71 (95\% IC 1,22 -6,02), episiotomia $16,0 \%$ vs 35,1 (OR 2.46 (95\% IC 1,27 - 4,74) e laceração de lábios 37,0\% vs 19,5\% OR 2,43 (95\% IC 1,18 - 5,01). Na posição vertical tiveram menor risco de laceração de $1^{\circ}$ grau $-37,7 \%$ vs $56,8 \%$. Entretanto, tiveram mais risco de laceração de $2^{\circ}$ grau e episiotomia OR 2,11 (95\% 1,02 - 4,35). O edema vulvar aumentou o risco de trauma espontâneo e episiotomia OR 3,99 (95\% IC 1,80 8,85. Conclusão: Esses dados confirmam a hipótese de que a posição lateral esquerda oferece menos risco de traumas perineais graves. Descritores: Enfermagem obstétrica; Tocologia/métodos; Parto normal/métodos; Postura; Períneo/lesões

\section{RESUMEN}

Objetivo: Evaluar si existe asociación entre el resultado perineal en posiciones de parto no convencionales. Métodos: Estudo clínico randomizado realizado en el Centro de Parto Normal de la ciudad de Itapecerica da Serra, SP, Brasil. La muestra fue de 158 nulíparas divididas aleatoriamente en la posición de parto lateral izquierdo (81 en el grupo experimental) y vertical semi-sentada (77 en el grupo control). Resultados: Las mujeres del grupo experimental presentaron menor edema vulvar - 13,6\% vs 29,9\%, OR 2.71 (95\% IC 1,22 -6,02), episiotomía 16,0\% vs 35,1 (OR 2.46 (95\% IC 1,27 - 4,74) y laceración de labios 37,0\% vs 19,5\% OR 2,43 (95\% IC 1,18$5,01)$.En la posición vertical tuvieron menor riesgo de laceración de $1^{\circ}$ grado $-37,7 \%$ vs $56,8 \%$. Entre tanto, tuvieron más riesgo de laceración de $2^{\circ}$ grado y episiotomía OR 2,11 (95\% 1,02 - 4,35). El edema vulvar aumentó el riesgo de trauma espontáneo y episiotomía OR 3,99 (95\% IC 1,80 - 8,85). Conclusión: Esos datos confirman la hipótesis de que la posición lateral izquierda ofrece menos riesgo de traumas perineales graves.

Descriptores: Enfermería obstétrica; Tocología/métodos; Parto normal/métodos; Postura; Perineo/lesiones

* Study in a birth center in the city of Itapecerica da Serra, Brazil.

${ }^{1}$ Full Professor at Health Woman Departament of Escola Paulista de Enfermagem, Universidade Federal de São Paulo - UNIFESP - São Paulo (SP), Brazill.

${ }^{2}$ Professor at Health Woman Departament of Escola Paulista de Enfermagem, Universidade Federal de São Paulo - UNIFESP - São Paulo (SP), Brazil.

${ }^{3}$ Doctor of Nursing. Coordinator for Obstetric Nursing Specialization Course at Adventist University Center - São Paulo (SP), Brazil. 


\section{INTRODUCTION}

The World Health Organization classifies the lithotomic position as a harmful practice during the parturition and recommends this should be eliminated. Nonetheless, it has been extensively used in Brazilian and American hospitals since the parturition was institutionalized ${ }^{(1)}$. Among other positions adopted by women during the parturition, we found the left lateral and upright positions, with the latter being the most used among the nonconventional positions ${ }^{(2)}$. Nurse midwives need a scientific basis to use the non-conventional positions and be able to offer women a free and clear choice.

The position assumed by women during labor and birth is influenced by several complex factors that can be determined by standards of culture, institutional protocols of behavior, and professional preferences that come into play during the labor period and birth. The laws of gravity and mechanical action applied to the physiology of parturition directly influence the fetus, and especially its head. The fetus moves through the vaginal channel following a path of least resistance; consequently, it is impacted by external and internal forces. These laws proved effective in upright positions, since the gravity and directional force during the expulsive phase of delivery are synergic ${ }^{(3)}$.

In regard to the position of women and the physiology of parturition, the importance is to regulate the effects of gravity on the fetus, which supports the muscle force during the period of expulsion. The efficacy of the muscle can be measured by frequency and intensity of the uterine contractions. Many times it is difficult to distinguish between the influence of gravity and the muscle force in several positions during parturition. However, it can be observed through a cause-and-effect interrelation ${ }^{(4)}$.

There is not enough literature establishing relationships between the birth position and the perineal outcomes. However, the evidence does show the risks and benefits for women according to the position adopted by the women during parturition. It is especially important to minimize the perineal traumas related to the birthing position $^{(5)}$. Few studies have been done about the risks and benefits of birthing positions during parturition to prevent the maternal mortality attributed to perineal traumas due to different positions.

Spontaneous perineal trauma can occur during the parturition, and obstetric nurses and physicians may need to do a surgical procedure (episiotomy) to increase the diameter of the vulval outlet and facilitate delivery. The perineal repair is an aspect of the parturition that affects millions of women all over the world and that can increase long-term maternal morbidity ${ }^{(6)}$. There is no doubt that among the routine interventions that determine important perineal changes, the episiotomy is the most used. Nowadays in Brazil, although it is already a common practice, recent research shows the selective use of episiotomy is increasing ${ }^{(7)}$. As to the factors that influence the maternal perineal outcomes, we can report the following: parity, birth weight, maternal position in the parturition, professional that assisted the parturition, use of compresses, pre-natal perineal massage, directed labour, head flexion technique during the cephalic unfixing, age, race, use of analgesis and anaesthesia, use of hyaluronidases enzyme, and episiotomy ${ }^{(8-9)}$.

In this study, our hypothesis was that in the left lateral position (LLP) there would be less occurrence of perineal edema and indication for episiotomy than in the halfsitting position. The purpose of this study was to evaluate if there were associations between the perineal outcomes and the LLP of the parturition versus the upright half-sitting (UHS)

\section{METHODS}

This was a clinical, randomized trial to investigate the LLP and the UHS position in the expulsive period of the parturition, in regard to perineal outcomes in nulliparous women assisted in the Normal Parturition Center (NPC). The population consisted of women assisted during the parturition by nurse midwives in the NPC, at Hospital Geral de Itapecerica da Serra, in the metropolitan region of Sao Paulo, Brazil.

This study was approved by the Committee for Ethics in Research. Women were admitted to the study during labour, after receiving oral and written information from the researchers and signing the consent forms. The inclusion criteria employed in the samples were: nulliparous women admitted at the first gestation period and parturition, single fetus, live birth, fetus well-flexed in cephalic presentation, and absence of maternal and fetal disease. The sample size totaled 158 nulliparous parturients, randomly divided into the experimental group or the control group.

Through the blinding technique, the parturition position adopted was not known, either by the parturient, nor by the nurse midwives during the dilatation period. The assortment of positions occurred in the second parturition period, using two identical and closed envelopes each containing the indication of the left lateral position or the upright half-sitting. During this period, eight women withdrew from participation; six of these women had an obstetric indication for cesarean section, and two had dystocia. For these reasons, these women were replaced in the sample. At the end of the study, 158 nulliparous parturients were allocated in the following manner: 81 in the experimental group (left lateral position) and 77 in the control group (upright half-sitting).

The experimental variable (independent) was the parturition positions:

- Left lateral ${ }^{(2)}$ position (LLP), the experimental variable, was characterized by the woman lying down on the left side, her right leg flexed toward the breast at the moment of the expulsion; her partner could function as her main support, although this was not required. The head of the bed was elevated to 15 degrees.

- Upright half-sitting (UHS) position, the control variable, was characterized by the woman with her body weight on her buttocks and her torso inclined 30 degrees behind from the upright axis ${ }^{(8)}$.

To test the hypothesis, dependent variables were 
selected after the woman assumed the position chosen for birth, as shown below:

- Vulvar edema - classified by the presence or absence of a lump or increase in volume in the vulvar region, during parturition and postpartum.

- Perineal result-the effects of parturition on the perineum and obstetric interventions done classified as: entire perineum, first and second-degree lacerations ${ }^{(8-9)}$, episiotomy ${ }^{(9-10)}$ and position of perineal lacerations - categorized as: labial, paraurethral, vaginal, furcula and perineal body ${ }^{(9)}$.

The data were collected on a monthly basis for a six month period ${ }^{(11)}$ by nurse midwives that worked at NPC of the hospital in which the study was performed, after specific theoretical and practical training in parturitional postures. The training of nurse midwives included scientific knowledge about the two birth positions, practical training and performance assessment of the nurse midwives in the obstetric care

The variables in the study were compiled into a database (Microsoft Excel). The statistical calculations were made with SPSS software, version 10.0, and presented in table formats. The level of significance was considered statistically significant when the $\mathrm{p}$-value was less than 0,05 .

\section{RESULTS}

Table 1 shows the sociodemographic characteristics of

Table 1 - Sociodemographic characteristics of the nulliparous assisted Normal Parturition Center

\begin{tabular}{|c|c|c|c|c|c|}
\hline \multirow{3}{*}{ Sociodemographic characteristics } & \multicolumn{4}{|c|}{ Groups } & \multirow{3}{*}{ p-value } \\
\hline & \multicolumn{2}{|c|}{ Experimental } & \multicolumn{2}{|c|}{ Control } & \\
\hline & $n=81$ & $\%$ & $\mathrm{n}=77$ & $\%$ & \\
\hline \multicolumn{6}{|l|}{ Color } \\
\hline White & 51 & 63.0 & 43 & 55.8 & \multirow{2}{*}{$0.362 q$} \\
\hline Non-white & 30 & 37.0 & 34 & 44.2 & \\
\hline \multicolumn{6}{|l|}{ Occupation } \\
\hline Athome & 62 & 76.5 & 57 & 74.0 & \multirow{2}{*}{$0.714 \mathrm{q}$} \\
\hline Out of home & 19 & 23.5 & 20 & 26.0 & \\
\hline \multicolumn{6}{|l|}{ Age } \\
\hline Medium & & 20.4 & & 20.9 & \\
\hline Average & & 19.0 & & 20.0 & \\
\hline Standard deviation & 81 & 4.9 & 77 & 4.1 & 0.135 \\
\hline Minimum/Maximum & & $15 / 40$ & & $14 / 30$ & \\
\hline
\end{tabular}

Q: Qui-Square test: p-value $<0.05$; Mann Test - Whitney p-valor $<0.05$

Table 2 - Perineal outcomes of birth care in left lateral and upright half-sitting positions in nulliparous assisted Normal Parturition Center

\begin{tabular}{|c|c|c|c|c|c|c|}
\hline \multirow{3}{*}{ Perineal outcomes } & \multicolumn{4}{|c|}{$\begin{array}{r}\text { Groups } \\
\end{array}$} & \multirow{3}{*}{ p-val ue } & \multirow{3}{*}{$\begin{array}{c}\text { OR } \\
(\text { I.C. } 95 \%)\end{array}$} \\
\hline & \multicolumn{2}{|c|}{ Experimental } & \multicolumn{2}{|c|}{ Control } & & \\
\hline & $\mathrm{n}=81$ & $\%$ & $\mathrm{n}=77$ & $\%$ & & \\
\hline \multicolumn{7}{|l|}{ Vulvar edema } \\
\hline Present & 11 & 13.6 & 23 & 29.9 & \multirow{2}{*}{$0.013^{*} \mathrm{Q}$} & 271 \\
\hline Absent & 70 & 86.4 & 54 & 70.1 & & $(1.22-6.02)$ \\
\hline \multicolumn{7}{|l|}{ Perineal result } \\
\hline Entire & 12 & $(14.8) 0.3$ & 10 & $(13.0)-0.3$ & \multirow{4}{*}{$0.031 * \mathrm{Q}$} & \multirow{4}{*}{$\begin{array}{c}246 \\
(1.27-4.74)\end{array}$} \\
\hline Laceration I grade & 46 & $(56.8) 2.4$ & 29 & $(37.7)-2.4$ & & \\
\hline Laceration II grade & 10 & $(12.3)-0.4$ & 11 & $(14.3) 0.4$ & & \\
\hline Episiotomy & 13 & $(16.0)-0.7$ & 27 & $(35.1) 2.7$ & & \\
\hline \multicolumn{7}{|c|}{ Position of lacerations labials } \\
\hline Yes & 30 & 37.0 & 15 & 19.5 & \multirow{2}{*}{$0.015^{*} \mathrm{Q}$} & 243 \\
\hline No & 51 & 63.0 & 62 & 80.5 & & $(1.18-5.01)$ \\
\hline \multicolumn{7}{|l|}{ Paraurethral } \\
\hline Yes & 5 & 6.2 & 2 & 2.6 & \multirow{2}{*}{$0.275 \mathrm{~F}$} & \multirow{2}{*}{-} \\
\hline No & 76 & 93.0 & 75 & 97.4 & & \\
\hline \multicolumn{7}{|l|}{ Vagina } \\
\hline Yes & 7 & 8.6 & 10 & 11.8 & \multirow{2}{*}{$0.508 \mathrm{Q}$} & \multirow{2}{*}{ - } \\
\hline No & 74 & 91.4 & 67 & 88.2 & & \\
\hline \multicolumn{7}{|l|}{ Furcula } \\
\hline Yes & 15 & 18.5 & 15 & 19.5 & \multirow{2}{*}{$0.878 \mathrm{Q}$} & \multirow[b]{2}{*}{ - } \\
\hline No & 66 & 81.5 & 62 & 80.5 & & \\
\hline \multicolumn{7}{|l|}{ Perineal body } \\
\hline Yes & 9 & 11.1 & 9 & 11.7 & \multirow{2}{*}{$0.909 \mathrm{Q}$} & \multirow{2}{*}{-} \\
\hline No & 72 & 88.9 & 68 & 88.3 & & \\
\hline
\end{tabular}


the study population, and demonstrates that it was homogeneous, with no statistically significant differences between groups. The majority were white (94), and were not employed outside the home (119). The average age was 20.7 years old. This homogeneity allowed us to presume that the high number of women that worked at home was related to the fact that the majority were young, having become pregnant at the end of the adolescence, without the opportunity to enter the job market.

In Table 2 we present our results. When evaluating the perineal outcomes in the comparative analysis between the groups, we observed a larger concentration of first grade lacerations in the experimental group $(56.8 \%)$ and less use of episiotomy $(16 \%)$.

In the control group, $35.1 \%$ of the women had an episiotomy, or nearly double that of the experimental group. These results were considered statistically significant (OR 2.46).

Table 3 shows the frequency of perineal swelling, along with the statistically significant association between vulvar edema and spontaneous perineal trauma or episiotomy. In women with edema present, a high percentage of second grade lacerations or episiotomy was identified, $\mathrm{OR}=3.99-$ I.C. $95 \%(1.80-8.85)$.

Table 3 - Perineal edema in nulliparous assisted to left lateral and upright half-sitting positions at Normal Parturition Center

\begin{tabular}{|c|c|c|c|c|c|}
\hline \multirow{3}{*}{$\begin{array}{l}\text { Vulvar } \\
\text { edema }\end{array}$} & \multicolumn{4}{|c|}{ Perineal ou tcomes } & \multirow{3}{*}{$\begin{array}{c}\text { Total } \\
(\%)\end{array}$} \\
\hline & \multicolumn{2}{|c|}{$\begin{array}{c}\text { Entire/ } 1^{\circ} \\
\text { grade laceratio }\end{array}$} & \multicolumn{2}{|c|}{$\begin{array}{c}2^{\circ} \text { grade laceration/ } \\
\text { episiotomy }\end{array}$} & \\
\hline & $\mathrm{n}$ & $\%$ & $\mathrm{n}$ & $\%$ & \\
\hline Present & 12 & 7.6 & 22 & 13.9 & 31.51 \\
\hline Absent & 85 & 53.8 & 39 & 24.7 & 78.49 \\
\hline Total & 97 & 61.4 & 6 & 38.6 & 100.0 \\
\hline
\end{tabular}

Risk factors associated with increased perineal laceration or episiotomy included being employed outside the home, the presence of vulvar edema, and fetal heart rate below 120 beats per minute (Table 4).

\section{DISCUSSION}

Although parturition and birth are physiological processes, the position adopted by the woman in this period has undergone alterations throughout history. Nowadays, mainly in western society, the parturitional posture usually used is the lithotomic position to facilitate monitoring of the fetus by obstetric professionals, nurses and physicians, to allow evaluation of the descent, and to intervene in the physiological process of parturition, without evidence of maternal or fetal benefits ${ }^{(1)}$. Women who are clients of the NPC have the opportunity to choose the best birthing position. The findings of this study permit us to evaluate scientific evidence of the effects on the LLP (experimental) and UHS (control) positions of 158 nulliparous attended at NPC by nurse midwives.

In a transversal study about factors related to perineal trauma in normal parturition in nulliparas ${ }^{(10,12)}$, there was a prevalence of white women experiencing perineal trauma, but not at a statistically relevant level. In two other studies, the authors afirmed that there were less cases of second degree laceration and more parturitions with intact perineum in black women ${ }^{(11-14)}$. Age was the next variable, and studies confirmed the absence of scientific evidence to associate perineal trauma to the maternal age, and emphasized the lack of significance in association between these variables ${ }^{(11,14-16)}$, confirming the findings of this study.

The vulvar edema presented more frequently in women in the upright half-sitting position $(29,9 \%)$; the difference between the groups was statistically significant with regard to this variable $(\mathrm{p}<0.013$; OR 2.71, 95\% IC, 1.22 - 6.02). The increased frequency of vulvar edema found in upright half-sitting position can be explained by the major compression of the tissues, caused by the position during parturition. This occurs because of gravity, the increasing force and the spontaneous labor in this position $^{(16-18)}$. In the upright half-sitting position during the intervals between contractions, the bascule movement is less intense as well as the presentation setback due to the gravity, which then avoids the setback and causes major compression on the vulvar region, consequently major frequency of vulvar edema.

The randomized controlled study of lithotomy parturition positions compared to the left lateral position in 104 primipara women conducted in the aforementioned study found in the left lateral position, $16.3 \%$ of intact perineums and the same percentage with first degree lacerations, $13.5 \%$ with second degree lacerations, and $6.7 \%$ with episiotomy ${ }^{(11,18)}$. The increasing use of episiotomy suggests that despite the fact that the population remains the same and is assisted by the same service, there is a variable not evaluated (time of experience of the group in the restricted use of episiotomy and management of left lateral parturition position and the upright half-sitting to make decision). However even with the increase of episiotomy in the study, the percentage is still less than the index of $20 \%$

Table 4- Risk factors of control group for second grade perineal laceration or episiotomy in nulliparous assisted at Normal Parturition Center

\begin{tabular}{lcccr}
\hline Factors of risk & Coeficient & Significancy (p-value) & Odds ratio & IC/odds ratio \\
\cline { 1 - 3 } Control Group-UHS* & 0.750 & 0.042 & 2117 & {$[1.029-4.354]$} \\
Occupation (Job) & 0.971 & 0.017 & 2.641 & {$[1.186-5.883]$} \\
Vulvar edema (present) & 1.504 & 0.001 & 4.498 & {$[1.906-10.616]$} \\
Fetal cardiac frequency $<120 \mathrm{bpm}$ & 1.577 & 0.003 & 4.839 & {$[1.706-13.724]$} \\
\hline * Upright half-sitting (UHS) & & & &
\end{tabular}


recommended by World Health Organization ${ }^{(1)}$.

There was high concentration of labial lacerations in the experimental group (37.0\%) as compared to $19.5 \%$ in the control group, considered statistically significant in this study ( $\mathrm{p}=0.015)$; this indicates the risk is 2.43 times higher than in the control group (Table 2). This is related to the decreasing use of episiotomy, as the literature indicates that the restricted use of episiotomy in nulliparas increases the risk of having the outcome of a first degree laceration as an expected occurrence ${ }^{(1,10)}$. It is useful to point out that the percentage of first degree laceration and reduction of intact perineums in this study relates to the fact that every case of excoriation or fissure, even with the absence of bloodshed, was considered to be a first degree laceration. It can be observed that there is a tendency to increase the number of first degree lacerations, decrease the frequency of second degree lacerations and of episiotomy, without increasing the frequency of third degree lacerations in the hospital where this study was conducted.

According to our professional experience, another aspect to be considered refers to the tendency, which is not intentional, of the professional to underestimate the degree of laceration. Perhaps this can be attributed to the concern of nurses and doctors to always cause the least harm and provide the maximum benefit to the individual for whom assistance is being provided. Thus, assessing the degree of laceration represents a challenge in obstetric care practice of nurse midwives ${ }^{(19)}$.

A randomized study of upright versus horizontal positions found 1.95 times more risk (95\% IC, 0.97 3.90) of having second degree lacerations in the upright position, and less use of episiotomy ${ }^{(20)}$. In a retrospective study of 2,118 normal deliveries in nulliparous women using different birthing positions at Normal Parturition Center, was it was discovered that $71.4 \%$ of lacerations in nulliparous women occurred without episiotomy, with $69.9 \%$ first degree, $29.9 \%$ second degree and $0.2 \%$ third degree lacerations ${ }^{(21)}$. These studies confirm our findings.

A randomised study with 517 women in upright and supine positions assisted by nurses in home birth during the second period of the parturition, reported the presence of vulvar edema; however no statistically significant difference was found between the groups. It was clinically verified that there was a higher frequency of vulvar edema in the upright half-sitting position (7) versus the supine position $(2)^{(20)}$. In the statistical analysis, using logistic regression, women in the upright half-sitting

\section{REFERENCES}

1. Organização Mundial da Saúde. Assistência ao parto normal: um guia prático. Brasília: PA/USAID; 1996.

2. Gupta JK, Hofmeyr GJ, Smyth RM. Position in the second stage of labour for women without epidural anaesthesia. Cochrane Database Syst Rev. 2000; (1):CD002006.

3. 3.Howard FH. The physiologic position for delivery. Am J Obstet Gynecol. 1959;78:1141-3.

4. Atwood RJ. Parturitional posture and related birth position had more than twice the risk of having second degree laceration or episiotomy than those women who gave birth to children in the left lateral position (OR $2.11,95 \%$ IC $1.02-4.35)$. Women who had an occupation outside of the home, the presence of vulvar edema, and the fetal heart rate of less than $120 \mathrm{bpm}$ were also at increased risk of perineal traumas.

In regard to fetal heart rate (FHR), its evaluation in the intervals of the contractions is of fundamental importance in parturition of low risk during the expulsion period, mainly when the routine episiotomy is not used. This is because alterations in the norms of the FHR signal the need to abbreviate the movements of the bascule in the expulsion period, as the great purpose of the parturition without episiotomy is to decrease the maternal morbidity and guarantee safe perinatal conditions ${ }^{(22)}$.

A randomized study of parturition positions in 100 women, with 50 in half-sitting position and 50 in dorsal position, concluded that late decelerations of FHR were less frequent in the half-sitting-position ${ }^{(23)}$. In the literature there is agreement with respect to the upright position and the reduction of the abnormality in or interventions due to FHR. In relation to the left lateral position, the review of literature indicates that the utero-placental flux is also better supported ${ }^{(23-24)}$.

In this research analysis, occupation outside of the home, the presence of vulvar edema, and the FHR of less than $120 \mathrm{bpm}$ were considered to be risks for second degree laceration or episiotomy, according to the odds ratio from each variable (Table 4).

\section{CONCLUSION}

Our study showed that women using the left lateral position (experimental group) experienced the benefits of less vulvar edema risk and fewer episiotomies; complications included a higher frequency of first degree labial lacerations than those women using the upright half-sitting position (control). Also, risk factors for second degree laceration and episiotomy in the upright half-sitting position were higher in women with an occupation outside the home, vulvar edema, and FHR less than $120 \mathrm{bpm}$

\section{ACKNOWLEDGEMENTS}

This study was financed by a grant from the CENFOBS (Center for Studies in Obstetrical Nursing).

behavior. Acta Obstet Gynecol Scand Suppl. 1976;57: 125.

5. Shorten A, Donsante J, Shorten B.Birth position, accoucheur, and perineal outcomes: informing women about choices for vaginal birth. Birth. 2002;29(1):18-27.

6. Kettle C, Hills RK, Ismail KM. Suturas continuas versus interrumpidas para la reparación de la episiotomía o los desgarros de segundo grado. In: La Biblioteca Cochrane 
Plus, n.2, 2008. Oxford: Update Software.

7. Brasil. Ministério da Saúde. Secretaria de Políticas de Saúde. Parto, aborto e puerpério: assistência humanizada à mulher. Brasília (DF); 2001. Assistência à mulher no parto normal; p.77-96.

8. Gupta N, Kiran TU, Mulik V, Bethel J, Bhal K. The incidence, risk factors and obstetric outcome in primigravid women sustaining anal sphincter tears. Acta Obstet Gynecol Scand. 2003;82(8):736-43.

9. Cunningham FG, MacDonald PC, Gant NF, Leveno KJ, Gilstrap LC, Hankins GD, et al. Conduta no trabalho de parto e parto normal. In: Williams obstetrícia. 20th ed. Rio de Janeiro: Guanabara Koogan; 2000. p.281-98.

10. Carroli G, Belizán J. Episiotomía en el parto vaginal.. In: La Biblioteca Cochrane Plus n.2, 2008. Oxford: Update Software.

11. Basile AL. Riscos e benefícios maternos e neonatais das posições lateral-esquerda e vertical semi-sentada no parto [tese]. São Paulo: Universidade Federal de São Paulo, Escola Paulista de Medicina; 2005.

12. Scarabotto LB, Riesco ML. Use of hyaluronidase to prevent perineal trauma during spontaneous delivery: a pilot study. J Midwifery Womens Health. 2008;53(4):353-61.

13. Howard D, Davies PS, DeLancey JO, Small Y. Differences in perineal lacerations in black and white primiparas. Obstet Gynecol. 2000;96(4):622-4.

14. Goldberg J, Hyslop T, Tolosa JE, Sultana C. Racial differences in severe perineal lacerations after vaginal delivery. Am J Obstet Gynecol. 2003;188(4):1063-7.

15. Klein MC, Janssen PA, MacWilliam L, Kaczorowski J, Johnson B. Determinants of vaginal-perineal integrity and pelvic floor functioning in childbirth. Am J Obstet Gynecol. 1997;176(2):403-10.

16. Klein MC, Gauthier RJ, Robbins JM, Kaczorowski J,
Jorgensen SH, Franco ED, et al. Relationship of episiotomy to perineal trauma and morbidity, sexual dysfunction, and pelvic floor relaxation. Am J Obstet Gynecol. 1994;171(3):591-8.

17. Howard FH. The physiologic position delivery. Am J Obstet Gynecol.1959;78:1141-3.

18. Bomfim-Hyppólito S. Influence of the position of the mother at delivery over some maternal and neonatal outcomes. Int J Gynaecol Obstet . 1998;63 Suppl 1:S6773.

19. Colacioppo PM, Riesco, MLG, Colacioppo, RC,e Osava RH. Avaliação do viés de classificação da laceração perineal no parto normal. Acta Paul Enferm. 2011; 24(1): 61-6.

20. de Jong PR, Johanson RB, Baxen P, Adrians VD, van der Westhuisen S, Jones PW. Randomised trial comparing the upright and supine positions for the second stage of labour. Br J Obstet Gynaecol. 1997;104(5): 567-71..

21. de Souza Caroci da Costa A, Gonzalez Riesco ML. A comparison of "hands off" versus "hands on" techniques for decreasing perineal lacerations during birth.J Midwifery Womens Health. 2006;51(2):106-11.

22. Brasil. Ministério da Saúde. Secretaria de atenção à Saúde. Área Técnica de Saúde a Mulher. Anais dos seminários nacionais sobre assistência obstétrica e neonatal humanizada baseada em evidências científicas. Brasília (DF): Ministério da Saúde; 2005. Assistência humanizada ao parto; p. 88.

23. Martilla M, Kajanoja P, Ylikorkala O. maternal half-sitting position in the second stage of labor. J Perinat Med. 1983;11(6): 286-9.

24. Caldeiro-Barcia R, Noriega-Guerra L, Cibils LA, Alvarez $\mathrm{H}$, Poseiro JJ, Pose SV, et al. The effect of position changes on the intensity and frequency of uterine contractions during labor. Am J Obstet Gynecol. 1960;80(2) :284-90. 